Jul 1st, 12:00 AM

\title{
Water Balance Modelling in Bowen, Queensland, and the Ten Iterative Steps In Model Development and Evaluation
}

Wendy D. Welsh

Follow this and additional works at: https://scholarsarchive.byu.edu/iemssconference

Welsh, Wendy D., "Water Balance Modelling in Bowen, Queensland, and the Ten Iterative Steps In Model Development and Evaluation" (2006). International Congress on Environmental Modelling and Software. 68.

https://scholarsarchive.byu.edu/iemssconference/2006/all/68

This Event is brought to you for free and open access by the Civil and Environmental Engineering at BYU ScholarsArchive. It has been accepted for inclusion in International Congress on Environmental Modelling and Software by an authorized administrator of BYU ScholarsArchive. For more information, please contact scholarsarchive@byu.edu, ellen_amatangelo@byu.edu. 


\title{
Water Balance Modelling in Bowen, Queensland, and the Ten Iterative Steps in Model Development and Evaluation
}

\author{
W.D. Welsh $^{\mathrm{ab}}$ \\ ${ }^{a}$ Bureau of Rural Sciences, GPO Box 858, Canberra ACT 2601, Australia \\ Email:wendy.welsh@brs.gov.au \\ ${ }^{b}$ Integrated Catchment Assessment and Management Centre, School of Resources, Environment and Society, \\ Building 48A, The Australian National University, Canberra ACT 0200, Australia
}

\begin{abstract}
This paper describes a Geographic Information System (GIS)-based method of estimating the water balance as applied to a coastal aquifer near Bowen, Queensland, Australia, using the ten interactive steps in development and evaluation of environmental models of Jakeman et al. [2006]. The $220 \mathrm{~km}^{2}$ Bowen irrigation area is data-rich with 260 observation bores plus stream gauging, metering of irrigation bores and detailed land use mapping. The method uses Darcy's Law, which defines the volumetric rate of flow through a tube of saturated medium as a relationship between the hydraulic conductivity of the medium, the hydraulic gradient in the tube and the cross-section area of the tube. The groundwater components in the study area are discretised into polygons to which Darcy's Law is applied to estimate the magnitude of the water balance components. The study calculated that, on average, aquifer recharge is $87 \%$ from rainfall and irrigation, $12 \%$ from rivers, and less than $1 \%$ from lateral inflow from adjacent groundwater storage. Of the groundwater discharges, on average, $66 \%$ is due to evapotranspiration, $28 \%$ is from groundwater pumping, $4 \%$ is submarine discharge, and $2 \%$ becomes river baseflow. The method proved cost and time effective and provided important insights to the groundwater dynamics of the area. The modelling approach is generally applicable to data-rich aquifers.
\end{abstract}

Keywords: Groundwater; Geographic Information System (GIS); Queensland; Model development

\section{INTRODUCTION}

Bowen is a coastal town in the dry tropics of Queensland, Australia. There are on average nearly 300 dry days per year, and the summerdominant rainfall is extremely variable, ranging from 255 to $2358 \mathrm{~mm} /$ year [Welsh 2002]. The adjacent Don River Delta irrigation area is one of the largest horticultural areas in the dry tropics of Queensland [Baskaran et al. 2001] and is groundwater dependent. With horticulture increasingly replacing grazing on the floodplain, the groundwater resource is under increasing demand, particularly during prolonged dry periods. A model was sought to assist with management of the groundwater resource.

\section{MODEL DEVELOPMENT EVALUATION}

The following discussion describes the model development and evaluation in terms of Jakeman et al.'s [2006] ten steps. Although the ten step generic treatment of the modelling process was not available during development of this model a similar approach, as described by Middlemis [2000], was standard for groundwater modelling.

\section{1 Model purpose}

A numerical groundwater model of the Bowen irrigation aquifer was requested by the Queensland Department of Natural Resources and Mines (QDNR\&M) to assist with management of the resource. At issue was overpumping of the groundwater and the possibility of this inducing sea water intrusion, which would contaminate the 
aquifer and further reduce the availability of the resource.

Traditionally, groundwater components have been quantified very approximately using back of the envelope methods, or more accurately by constructing complete numerical groundwater flow models using packages such as MODFLOW [McDonald \& Harbaugh 1988]. The intention initially was to provide a MODFLOW finitedifference model that would be time-consuming to develop but would provide a quantitative predictive capacity. The model needed to be transient because of the seasonal nature of rainfall recharge and irrigation pumping.

Resources were reduced part-way through the project due to changed corporate priorities. This necessitated a re-think of the achievable outputs, and a GIS-based approach was developed as a compromise between model accuracy, usefulness and timeliness. The GIS-based approach is a useful step between a conceptual model and a numerical model and is considered to have general applicability to other data-rich aquifers.

The purpose of the modelling was not to assess the risk of sea water intrusion, but to provide a sound basis for managing the water resources sustainably through an improved understanding of the groundwater dynamics and a quantification of the groundwater components over space and time.

\section{2 Modelling context: scope and resources}

QDNR\&M were the clients for the model and the point of first contact for data and information. The irrigators and the Bowen Shire Council may also have been interested, but had no direct input to the modelling.

The model was required to quantify the groundwater distribution and the important recharge and discharge mechanisms. The outcome would be a better understanding of the physical framework of the system (i.e. the aquifer geometry and properties) and the behaviour of the water within this framework as it interacts with water outside the framework.

The purpose of the model dictated that it extend over a few years to highlight observed trends. Time was discretised into 28-day intervals, commencing 18 June 1989 and terminating between 7 June 1997 and 8 April 2000 depending on the available data. A longer time interval would have blurred seasonal variations and a shorter time interval would have given less reliable water table surfaces as these measurements were generally bimonthly.
Spatially, the model needed to extend over both the extensively cropped river delta and inland over the increasingly cultivated floodplain. To reduce potential errors in the calculations the study area boundary was chosen to minimise the amount of groundwater flowing across it. Where possible the boundary coincides with the edge of the saturated aquifer or is parallel to the direction of groundwater flow. Areas of outcropping basement are not included.

The study area was discretised into polygons whose sizes were influenced by the density of the data and chosen to show an estimate of the spatial variation of the water balance components. Polygon sizes vary from $0.04 \mathrm{~km}^{2}$ to approximately $5 \mathrm{~km}^{2}$, as discussed in Sections 2.5.3 to 2.5.5.

One person was allocated to the project over a total of approximately 1 year.

\section{3 System conceptualisation, specification, prior knowledge}

data

The Don River irrigation area (Figure 1) covers about $220 \mathrm{~km}^{2}$ and occupies a valley open-ended to the ocean in the north. Euri Creek lies along the western edge and the Don River lies along the east. Both contribute to groundwater recharge and are ephemeral. Each has one stream gauge whose average water levels were used in calculations of the groundwater / surface water interactions in the rivers.

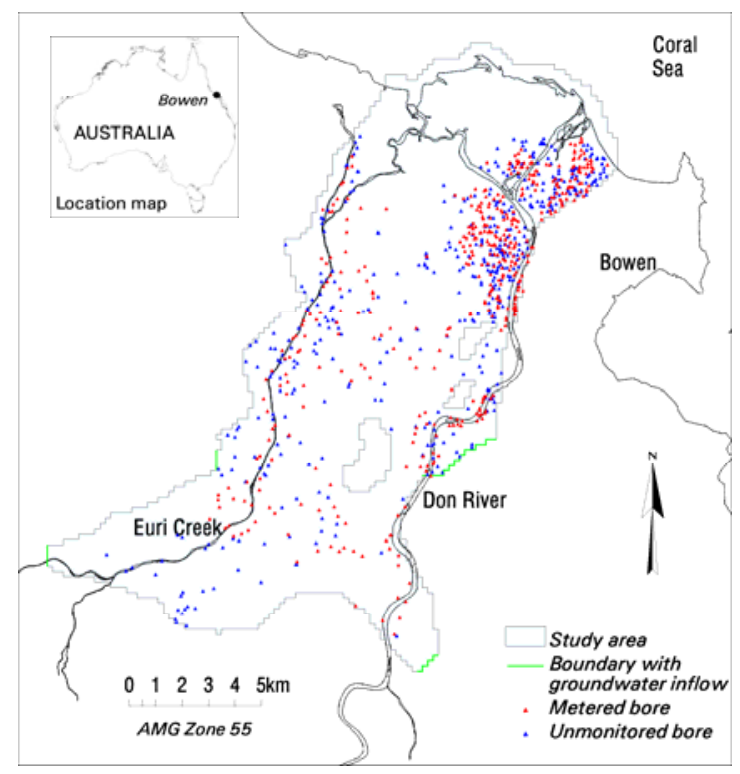

Figure 1. Location of production bores within the study area. 
The aquifer consists of unconsolidated fluviodeltaic deposits and weathered granite, which has the appearance of medium to coarse sand [Welsh 2002]. Production bores are screened in both lithologies. Preferential groundwater flow occurs in the more transmissive zones of the infilled channels formed by the unweathered granite that is assumed to be hydraulic basement. The aquifer is unconfined and groundwater flow is from the south toward the coast.

The alluvial sediments are thickest at the coast and the weathered granite is thickest in the south. Because the water table deepens toward the south, the saturated part of the aquifer is mostly alluvial sediments in the north grading to mostly weathered granite in the south.

Conceptually, water enters the aquifer as deep drainage of rainfall and excess irrigation through the soil, laterally from up-gradient parts of the aquifer outside the study area and through the riverbed sediments when the river water elevation is greater than the water table elevation. Water exits the aquifer as fresh water discharge to the sea, through water bores, as river baseflow and via evapotranspiration. Groundwater storage changes by the difference between the inflows and outflows.

In recognition of the aquifer's stressed nature and economic importance to the region, data collection and monitoring has been a high priority. There are 726 bore hole lithological logs, water levels from 260 dedicated monitoring bores, including 10 multi-piped bores near the coast, 6 bores with pump-test transmissivities, metered water use read 4 to 5 times annually from 454 production bores, the locations of 469 unmetered stock and domestic bores, air photos and mean daily river heights at two locations. In addition, topography, surface geology, bottom elevation of the alluvial sediments, rainfall, pan evaporation rates, soil type and texture, and land use mapped at a scale of $1: 25,000$ in 2000 were available from other sources. The model assumes that the meteorological components were spatially uniform.

\section{4 Selection of model features and family}

The model is data-driven. It consists of simple representations of physical fluxes using variations of Darcy's Law, which describes laminar water flow through soils. The equations calculate water balance components over space and time. All model parameters are distributed except the storage coefficient and deep drainage recharge from rainfall and excess irrigation, which are lumped parameters determined during calibration. All other water balance components are calculated independent of each other.

The water table elevation is pivotal in determining all components of the water balance except the bore discharges. The simulation model does not move water laterally between polygons. It calculates recharge or discharge based on water level differences, except evapotranspiration, which uses water table depth to regulate discharge.

The model is not predictive. By interpolating past measurements to a set of points in time it exposes the trends and relationships of the water balance elements.

\section{5 Selection of model structure and parameter values}

As a numerical model was the suggested product of the study, and MODFLOW is the industry standard for groundwater flow models, this influenced the choice of model structure. Like MODFLOW, this model is based on Darcy's Law, and its application involves discretising and simplifying the groundwater system components so that the important processes are captured. The model structure is spatially-based with simple physics applied within and between polygons.

\subsubsection{Preliminary data processing}

Water level measurements in the multi-piped bores were used to ascertain that the permeable lithologies at different depths could be modelled as a single aquifer. The water levels in each set of pipes were compared after correcting for density variations due to salinity.

Water table measurements from monitoring bores, both inside and outside the study area, were interpolated to the model timesteps after adjustment to a common datum using topographic data and correction for density variations.

The lithological logs were used to calculate point estimates of saturated-zone horizontal hydraulic conductivity $\left(K_{h}\right)$ of the alluvial sediments using standard conductivities for the lithologies [Freeze and Cherry 1979]. These were then calibrated against the transmissivity measurements. Estimated alluvial $K_{h}$ in the saturated zone varies between 0.1 and $100 \mathrm{~m} /$ day. Based on the appearance of the weathered granite and the standard conductivities, the weathered granite was assigned a constant $K_{h}$ of $20 \mathrm{~m} /$ day. 


\subsubsection{Water bore discharges}

Discharge volumes from metered irrigation bores were summed for the model timesteps and an estimate of use from stock and domestic bores, based on published household use from nearby regions [AWA 2002], was added to give the bore discharge rates, $Q_{b o r e}$.

\subsubsection{Coastal outflows}

Estimates of fresh water discharge to the sea were calculated for 14 coastal polygons (Figure 2) oriented parallel to the direction of groundwater flow and extending from the 2 metre hydraulic head contour to sea level. The relation uses the Ghyben-Herzberg Concept that in a coastal aquifer the depth of the fresh water/sea water interface is approximately 40 times the head of fresh water above mean sea level at that location [Freeze and Cherry 1979] due to the density difference between the two media.

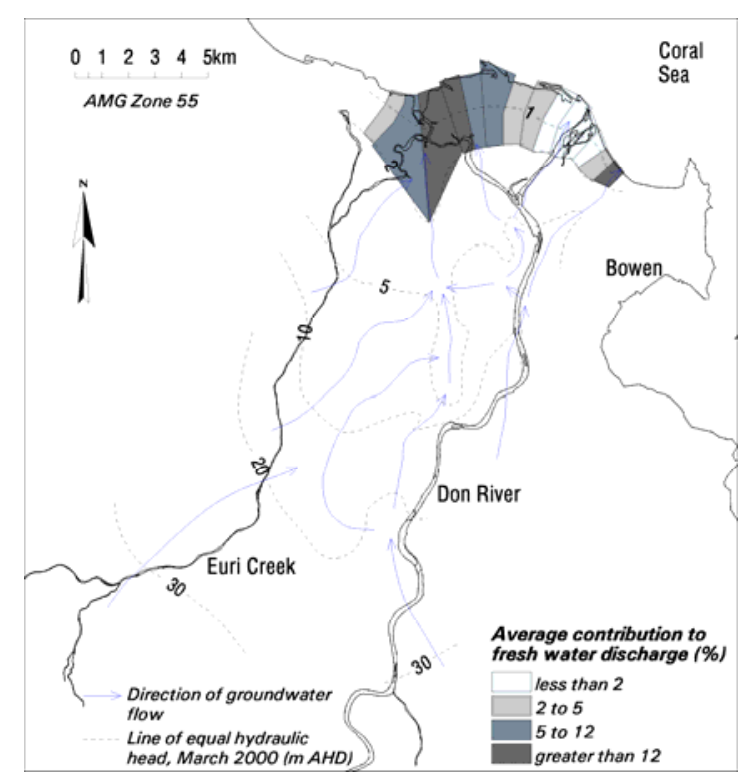

Figure 2. Coastal discharge polygons and groundwater flow directions.

These are combined in Darcy's Law, in which the volumetric rate of flow through a tube $Q$ is the negative product of the hydraulic conductivity $K$, the hydraulic gradient $d H / d L$ and the crosssection area $A$ of the saturated media [Freeze and Cherry 1979]:

$Q=-K \frac{d H}{d L} A$
Each coastal polygon is treated as a tube with a hydraulic gradient given by the drop in hydraulic head ( $H_{\max }-0=2$ metres, in this case) divided by the average polygon length $L_{a v}$ and a crosssection area as the average polygon width $W_{a v}$ by 41 times the average height of fresh water above mean sea level $H_{a v}$. It is assumed that the average hydraulic head represents the average depth of fresh water. The coastal groundwater discharge is calculated as:

$Q_{\text {coast }}=K_{h} \frac{H_{\max }-0}{L_{a v}} 41 H_{a v} W_{a v}$

[after Queensland Department of Natural Resources and Mines 2000].

The discharge was calculated for each polygon in each 28-day period.

\subsubsection{River interactions}

Water flow between the Don River / Euri Creek and the aquifer was calculated for 16 and 9 river polygons respectively for each 28-day period.

Darcy's Law is applied to vertical tubes whose cross-section areas $A$ are the polygon areas. Hydraulic conductivity is the vertical hydraulic conductivity of the riverbed sediments $K_{z}$, tube length is the thickness of the riverbed sediments $L_{\text {riv }}$ and the change in hydraulic head is the difference between the river stage $H_{r i v}$ and the water table elevation $H$ :

$Q_{\text {river }}=K_{z} \frac{H_{r i v}-H}{L_{r i v}} A$

[after McDonald \& Harbaugh 1988]. A negative $Q_{\text {river }}$ represents groundwater discharging into the river; a positive $Q_{\text {river }}$ represents river water recharging the aquifer.

Groundwater discharges when the river stage is below the elevation of the water table. Conversely the river loses to the aquifer when the river stage is above the water table elevation. Horizontal flow between the aquifer and the river is assumed to be negligible.

Riverbed outlines were digitised from air photos; stream-bed thickness was estimated from published information [WRC 1988]; water depths were assumed to be constant along the lengths of 
the rivers and to correspond to the relevant gauging stations; and a constant value of 0.01 metres/day was assumed for $K_{z}$ based on knowledge of similar systems.

\subsubsection{Evapotranspiration}

Evapotranspiration is a combination of evaporation from open bodies of water, evaporation from soil surfaces and transpiration from the soil by plants. This study considers only evapotranspiration losses extracted from groundwater storage by vegetation.

The rate of evapotranspiration is a portion of measured pan evaporation and is a function of soil type, land use and root extinction depth. Evapotranspiration is assumed to be zero when the root zone is entirely above the water table.

The maximum evaporation rate $E_{\max }$ was taken to be $85 \%$ of the measured pan evaporation rate. The mapped land uses were reduced to 8 classes for the purpose of assigning root extinction depths, which are listed in Table 1. Root depths for loamy sediments are reduced to $90 \%$ of the listed values.

Table 1. Estimated maximum root extinction depths.

(a) Maximum root depths for irrigated agriculture vary from $0.01 \%$ to $100 \%$ of 2 metres from January/February to December each year.

(b) Rivers were assigned an evapotranspiration of zero because river-aquifer interactions dominate their water balance.

(c) Other water bodies were assigned the maximum evapotranspiration.

\begin{tabular}{lc}
\hline Vegetation type & Root extinction depth (m) \\
\hline Mangroves & 2 \\
Irrigated horticulture & (a) 2 \\
Cleared pasture & 1 \\
Improved pasture & 1.5 \\
Near-shore native vegetation & 2 \\
Other native trees & 5 \\
Rivers & (b) - \\
Other water bodies & (c) - \\
\hline
\end{tabular}

Evapotranspiration $Q_{\text {evap }}$ is estimated as the product of $E_{\max }$ and the proportion of the root zone that is below the water table, which is calculated using the ground surface elevation $G$, the water table elevation $H$ and the root extinction depth $D_{\text {ext }}$ :

$Q_{\text {evap }}=E_{\max } \frac{D_{e x t}-(G-H)}{D_{\text {ext }}}$

[after McDonald \& Harbaugh 1988].

Evapotranspiration was calculated for each 28-day period with the study area discretised into approximately 5000 cells, each 200m x 200m.

\subsubsection{Lateral inflows}

Groundwater flows into the study area across four sections of the boundary (Figure 1). The flow rate was calculated across $200 \mathrm{~m}$ edge length square boundary cells using Darcy's Law. The hydraulic gradient is the change in hydraulic head $\Delta H$ along the length of the cell $L_{\text {cell }}$; the cross-section area is the product of cell width $W_{\text {cell }}$ and the saturated aquifer thickness $D_{\text {aquifer }}$ :

$$
Q_{\text {lateral }}=K_{h} \frac{\Delta H}{L_{\text {cell }}} W_{\text {cell }} D_{\text {aquifer }}
$$

\subsubsection{Storage}

Aquifer storage is the volume of saturated media between the water table and hydraulic basement multiplied by the specific yield, which can be thought of as drainable porosity.

Saturated aquifer volumes were calculated at 28day intervals using time-varying hydraulic head surfaces and the hydraulic basement surface in the GIS. The specific yield was estimated during model calibration.

\subsubsection{Rainfall and irrigation deep drainage}

Rainfall recharges the aquifer predominantly in the wet summer months. As most crops are planted at the end of the wet season, irrigation deep drainage contributes to recharge in the dry months. As detailed crop information was not available this component of recharge is calculated as a lumped parameter during calibration.

\section{6 Choice of estimation performance criteria and technique}

Although plant root extinction depths were modified slightly during calibration, specific yield 
and deep drainage recharge were the only model inputs entirely determined during parameter estimation. Parameter values were adjusted manually during the calibration.

Invoking the relation for change in storage:

$$
\Delta S=\text { Inflows }- \text { Outflows }
$$

allows an estimate of rainfall and irrigation deep drainage when the equations are re-arranged as:

$$
\begin{aligned}
Q_{\text {recharge }}= & \Delta S+Q_{\text {bore }}+Q_{\text {coast }}+Q_{\text {evap }} \\
& -Q_{\text {river }}-Q_{\text {lateral }}
\end{aligned}
$$

This equation describes the water balance for each time period. Since recharge is by definition into the ground, and therefore positive, specific yield was modified to ensure that deep drainage recharge rates were not negative in any 28-day period. Specific yield was estimated as a single value (0.06) because specific yield, or more broadly storage coefficient, is usually the least sensitive parameter in numerical groundwater models.

\section{7 Identification of model structure and parameters}

Data were collected and datasets were prepared for a MODFLOW steady state model. This model facilitated understanding of the hydrogeology of the area and was a test of the conceptual model. It was run with a range of recharge estimates, but was not calibrated.

At this time a change in corporate priorities required the Bowen modelling to be deferred. When the project resumed the time remaining for completion was only a few months.

To continue with MODFLOW would have required the development of a transient model because of the seasonality of the irrigation and the groundwater recharge. A steady state model would not add much to the understanding of the hydrogeology. The data were suitable but it was thought that the combined data processing and calibration process might not be completed in the timeframe.

The area is data-rich compared to most Australian groundwater basins. A method of extracting information from the data was sought that was spatial and temporal and would not involve a protracted calibration. Coastal outflows were first calculated using a modified version of an equation in QDNR\&M [2000]. This lead to the realisation that other components of the water balance could be calculated by using applications of Darcy's
Law and borrowing equations from MODFLOW. Using (6) enabled the missing component, recharge, to be estimated, creating the complete analytical water balance.

\section{8 Conditional verification and diagnostic testing}

As the model is not predictive there are no measured minus modelled residuals with which to make an assessment of the calibration. The modelled water balance was compared to results from a study of the Lower Burdekin aquifer in the Burdekin River Delta [QDNR\&M 2001], which lies 100 kilometres to the north-west. The outputs were also plotted against rainfall, which was not otherwise used in the model.

The effect of changes in parameter values on the water balance was determined for weathered granite $K_{h}$, unmetered bore flow rates, riverbed thickness and $K_{z}$, specific yield and evapotranspiration parameters. With each sensitivity analysis the remaining components of the model were recalculated, providing calibrated sensitivity results.

A water balance with the line items listed in Table 2 was compiled after each model run. Although individual components changed significantly from their baseline values, the total inflows and outflows changed little in most sensitivity runs. Figure 3 shows the effect of the parameter value changes on the total water balance inflows and outflows compared to the baseline calibrated model. For example, halving all root extinction depths reduces both total inflows and total outflows by $28 \%$.

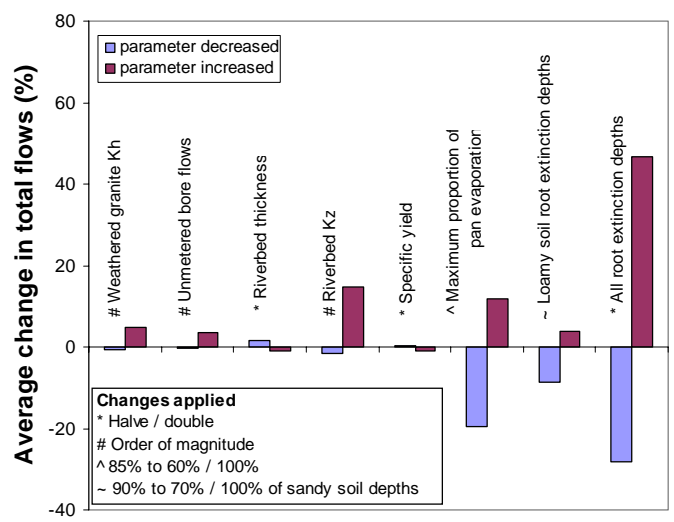

Figure 3. Mean changes in total flows for the sensitivity analyses. 
Rather than testing the effect of changes to one water balance component on other individual components, the sensitivity analyses test the implications of using different parameter values. For example, reducing root extinction depths reduces the evapotranspiration estimates (Equation (4)). This in turn decreases the estimates of recharge (Equation (7)). Because the model data are historical the water table elevations are fixed, and so are the temporal volumes of groundwater in storage. In the sensitivity analyses total inflows and total outflows will increase together or decrease together because of (6).

Hydraulic conductivity was changed by a large amount because it has a power relation with grainsize [Freeze and Cherry 1979], meaning that a small change in aquifer grainsize will have a large effect on both $K_{h}$ and $K_{z}$.

Changes to weathered granite $K_{h}$ and riverbed thickness caused significant differences in the lateral flows and river leakages respectively, but only small differences from the baseline model in the water balance totals. Changing unmetered bore flow rates also had little impact because stock and domestic bore water use is very much less than irrigation use.

Although deep drainage recharge and the water balance for individual stress periods are sensitive to changes in specific yield, the average flows over all 28-day periods did not change significantly because the increases and decreases balance out. The calculated deep drainage recharge in some 28day periods became negative with the higher specific yield.

The water balance is sensitive to decreases in riverbed $K_{z}$.

Evapotranspiration occurs over a large area and is the largest component of the water balance outflows. Varying the maximum rate from $85 \%$ of the pan evaporation rate to $60 \%$ and $100 \%$ had a significant impact on the total flows. The root extinction depth matrix (Table 1) is the most sensitive parameter. Altering these depths for loamy soils from $90 \%$ to $70 \%$ and $100 \%$ had a small impact on the water balance. However, halving all root extinction depths decreased total average inflows and outflows by nearly $30 \%$ and reduced the calculated deep drainage recharge to $15 \%$ of rainfall. Doubling root extinction depths increased total average inflows and outflows by nearly 50\% and increased the calculated deep drainage recharge to $34 \%$ of rainfall.

\subsection{Quantification of uncertainty}

The uncertainty associated with the selected modelling method and with the adopted discretisation has not been quantified.

The measured water levels drive the model. The monitoring bores are sufficiently spaced to allow a good interpolation of the water table surface except in part of the central east of the study area where the hydraulic gradient is very steep. More measurements in this area would give greater confidence to the interpolations. The 28-day time steps used by the model are the minimum that the data could sustain. There will be some error associated with this, but the likely effect is that temporally local maxima and minima were not captured by the data.

Comparisons between irrigation bore discharge rates and the other water balance components are of particular interest to water managers. Unfortunately these discharge records were incomplete. Plotting water use against rainfall highlighted some zero-values when pumping would be expected to be high in the last full year of data. The pumping data also had the shortest time-series - no data were available beyond May 1997.

Although the modelling outputs are quantitative, the water budgets are most reliably viewed as qualitative - showing where and when the individual components increase or decrease. Approximate relationships, such as the relative amounts of river water that replenishes the aquifer as compared to the amount of groundwater that is lost to the river, are likely to be quite reasonable.

\section{10 Model evaluation or testing}

The initial request for a numerical groundwater model was met in part: the model produced by the study succeeds in quantifying the important components of the groundwater system but does not include a predictive capacity. The model makes good use of the available data and provides an incremental improvement in the understanding of the Don River groundwater system.

The model was developed with input from QDNR\&M staff and documented in a 70-page report [Welsh 2002] listing the assumptions, detailing the methodology and illustrating the parameter sets and results. A draft of the report was distributed to both central office and regional QDNR\&M staff, as well as two Bureau of Rural Sciences staff and an independent reviewer for comment. 
The input parameters are considered to be plausible, being based on field measurements and knowledge of similar systems. It is not possible to validate the model against data not used in its construction because additional data were not available.

\section{RESULTS}

Figures 2, 4, 5 and 6 illustrate the spatial distributions determined for discharge to the sea, river leakage and evapotranspiration.

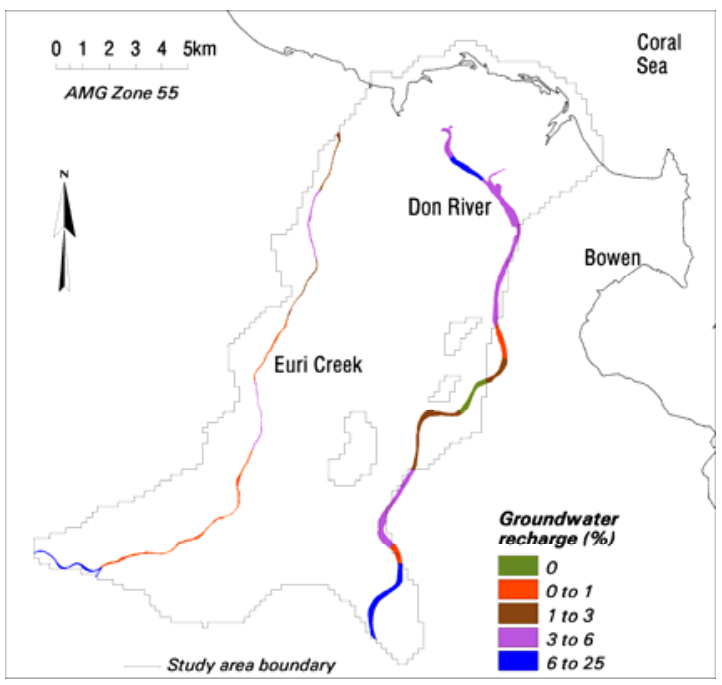

Figure 4. Average estimated proportion of river water recharging the aquifer.

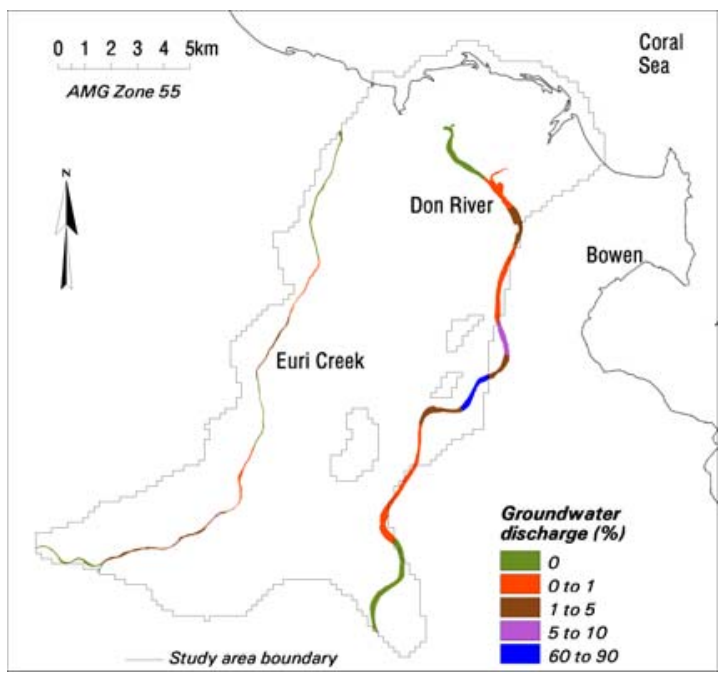

Figure 5. Average estimated proportion of groundwater discharging to the rivers.

Submarine discharge is greatest from the western part of the coast.
The Don River loses water to the aquifer along both its upstream and downstream reaches, while baseflow enters the River near the centre of the study area. Euri Creek is a dominantly losing stream.

The highest rates of evapotranspiration occur near the coast and adjacent to the rivers where the watertable is shallowest. Areas where the root zone is entirely above the water table are shown as having no evapotranspiration losses from groundwater storage.

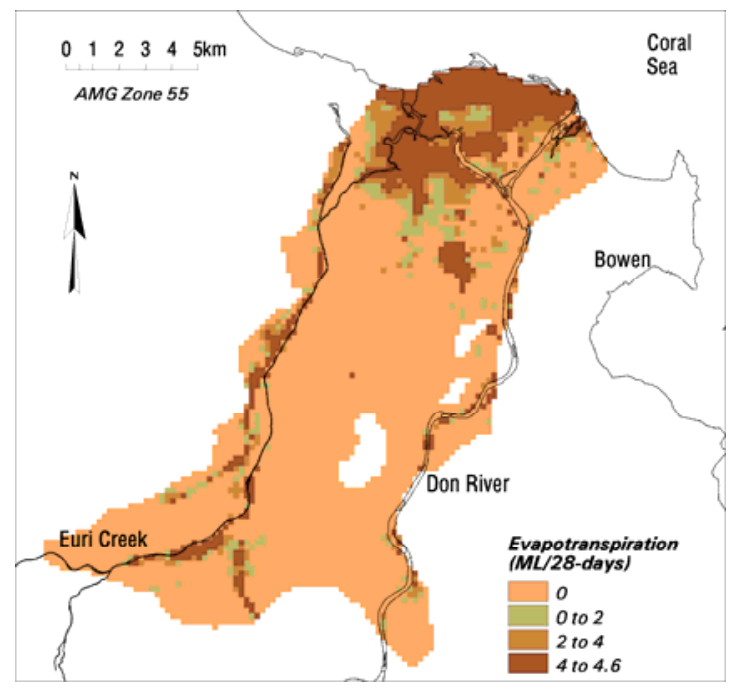

Figure 6. Estimated evapotranspiration losses from the groundwater for March 2000 calculated from $200 \mathrm{~m}$ x $200 \mathrm{~m}$ polygons.

Figures 7 to 12 compare the calculated time series of discharge to the sea, river leakage, evapotranspiration, lateral inflows, groundwater storage and recharge respectively with rainfall.

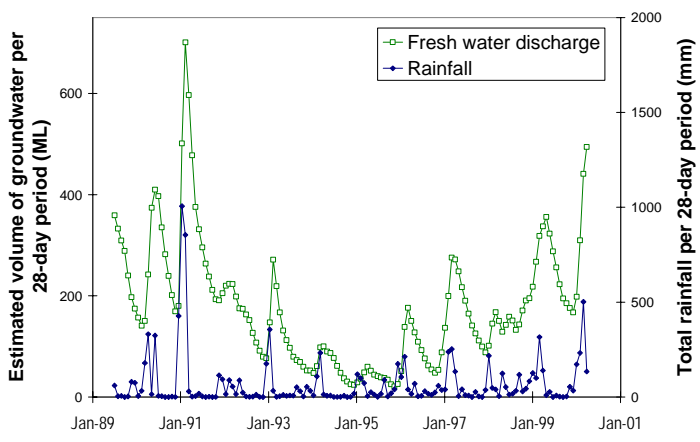

Figure 7. Estimated volume of groundwater flowing to the coast per 28-day period.

All parameters show strong seasonal variations. Recharge from rivers and deep drainage increases with rainfall, with the response to early summer rains being proportionately greatest. Groundwater 
storage, discharge to rivers, coastal outflows and lateral inflows increase with rainfall and gradually decrease during the year.

Figure 8 shows that the volume of water discharged into the rivers increases with the summer rains then tapers off as water drains from the aquifer. River recharge increases during the first month after the start of the summer rains, as the rivers fill. As the water table rises the height difference between it and the river decreases, so the rate of recharge decreases. River recharge then increases again as the water table drops.

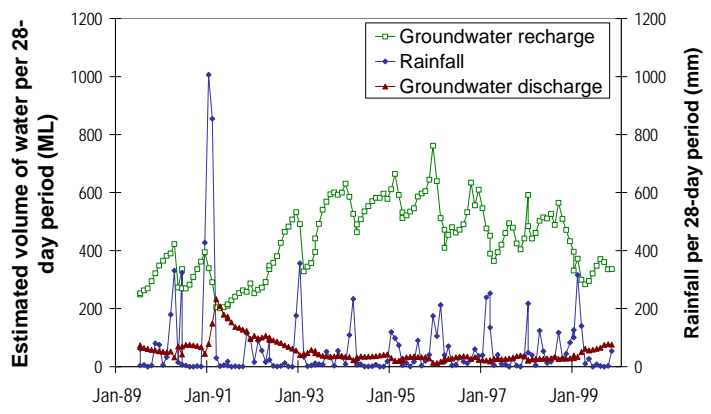

Figure 8. Estimated groundwater discharge into the rivers and recharge from the rivers for each 28day period.

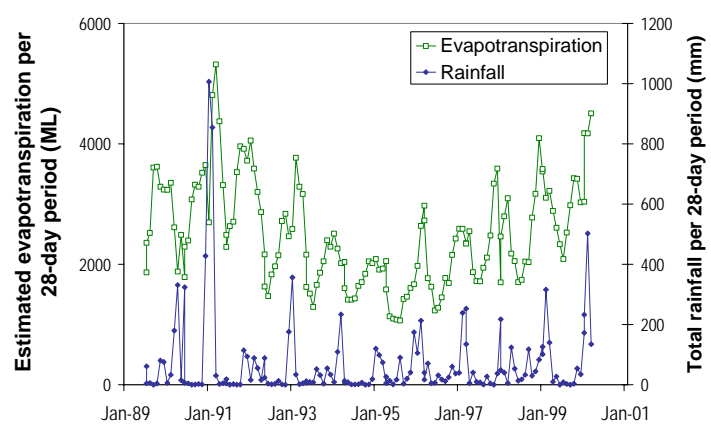

Figure 9. Estimated evapotranspiration losses from the study area groundwater for each 28-day period from July 1989 to March 2000.

The estimated recharge rates, as illustrated in Figure 12, suggest that the December 1990 / January 1991 flood doubled the maximum recharge rate for that wet season and enhanced the recharge for years afterward. They also suggest that relatively small rainfall events do contribute to groundwater recharge.

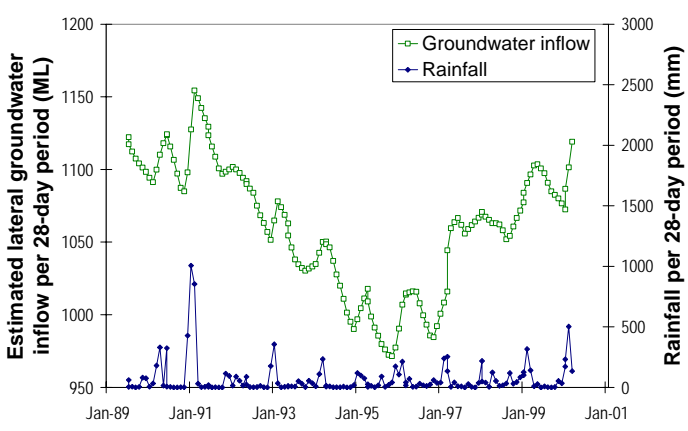

Figure 10. Estimated lateral inflows to the study area groundwater for each 28-day period from July 1989 to March 2000.

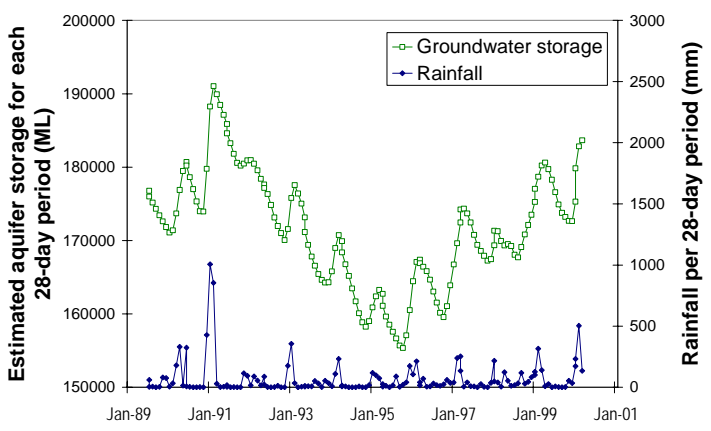

Figure 11. Estimated groundwater storage in the study area for each 28-day period from July 1989 to March 2000.

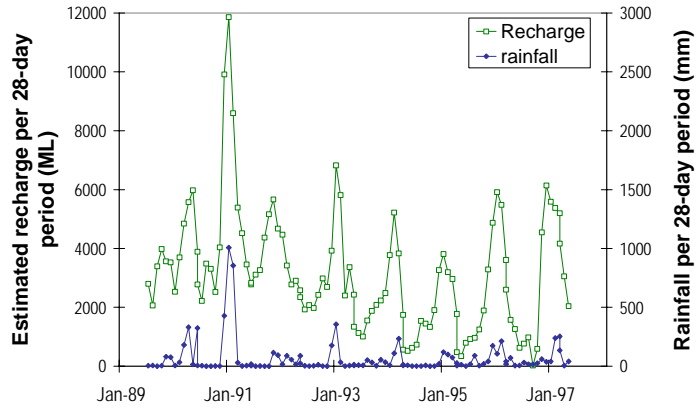

Figure 12. Deep drainage recharge calculated from changes in storage and the other water balance components.

The calibrated values of both the specific yield and deep drainage recharge are plausible when compared with estimates for the Lower Burdekin aquifer. The Bowen specific yield of 0.06 lies within the 0.05 to 0.15 range estimated for the Lower Burdekin.

The recharge rates estimated are about $20 \%$ of the average annual rainfall. This compares with 35\% 
for the Lower Burdekin, of which about one quarter is artificial recharge through purpose-built recharge pits.

The estimated water balance for the study area for selected periods is shown in Table 2. The 12 January 1991 period has the highest rainfall, 1 May 1993 is in the dry season prior to the mandated move from flood to trickle irrigation and has the greatest groundwater pumping, and 11 November 1995 has the lowest water table. A time series plot of the water balance components except lateral inflow and groundwater storage, which are the smallest and largest components, is shown in Figure 13.

Table 2. Estimated water balance for a selection of 28-day periods for the study area. Volumes are ML per 28-days.

\begin{tabular}{|c|c|c|c|c|}
\hline Component & $\begin{array}{c}12 \\
\text { Jan } \\
1991\end{array}$ & $\begin{array}{c}1 \\
\text { May } \\
1993\end{array}$ & $\begin{array}{c}11 \\
\text { Nov } \\
1995\end{array}$ & $\begin{array}{l}\text { Average } \\
\text { Jul } 1989 \text { to } \\
\text { May } 1997\end{array}$ \\
\hline \multicolumn{5}{|l|}{ Inflows } \\
\hline $\begin{array}{r}\text { Deep } \\
\text { drainage }\end{array}$ & 11,861 & 2427 & 3287 & 3138 \\
\hline Rivers & 339 & 395 & 644 & 435 \\
\hline $\begin{array}{r}\text { Lateral } \\
\text { flows }\end{array}$ & 32 & 30 & 27 & 30 \\
\hline Total & 12,232 & 2852 & 3958 & 3603 \\
\hline \multicolumn{5}{|l|}{ Outflows } \\
\hline Rivers & 78 & 54 & 28 & 59 \\
\hline $\begin{array}{r}\text { Lateral } \\
\text { flows }\end{array}$ & 501 & 131 & 21 & 163 \\
\hline Water bores & 478 & 2391 & 564 & 1004 \\
\hline $\begin{array}{r}\text { Evapotrans- } \\
\text { piration }\end{array}$ & 2698 & 2158 & 1604 & 2407 \\
\hline Total & 3755 & 4734 & 2217 & 3633 \\
\hline In - Out & 8477 & -1882 & 1741 & -30 \\
\hline
\end{tabular}

The model results suggest that, on average:

1. Deep drainage from rainfall and irrigation is about $87 \%$, river leakage is about $12 \%$ and lateral groundwater inflow into the study area is less than $1 \%$ of the recharge

2. Evapotranspiration is about $66 \%$, water bores are about $28 \%$, fresh water flow to the ocean is about $4 \%$ and drainage into the rivers is about $2 \%$ of the groundwater losses
3. Groundwater pumping uses about 6 times the amount of fresh groundwater that flows out to the sea

4. Don River and Euri Creek contribute close to half of the volume of groundwater that is removed by pumping

5. About 7 times more river water replenishes the aquifer than groundwater is lost to the river

The annualised average water balance figures for July 1989 to May 1997 are illustrated in Figure 14.

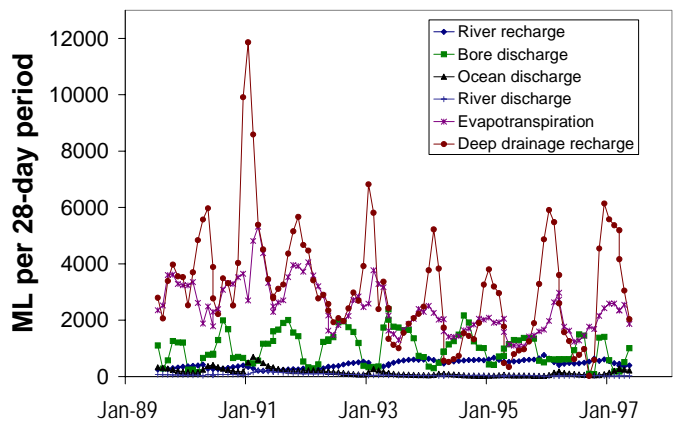

Figure 13. Time series of average water balance component values.

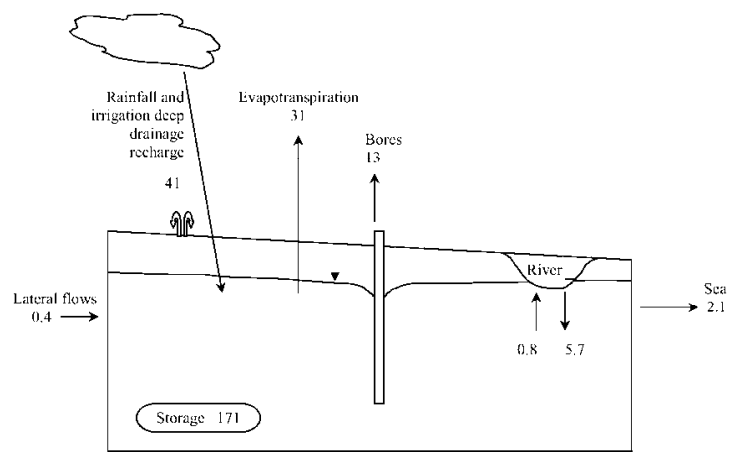

Figure 14. Estimated annual average water balance (GL) for the period July 1989 to May 1997.

\section{DISCUSSION AND CONCLUSIONS}

This paper presents algorithms that are mostly based on Darcy's Law and provide simple estimates of the water balance for the Don River Aquifer. A GIS is critical to the method, being used to spatially interpolate point data and to calculate aquifer volumes. The equations capture the important flows while simplifying the groundwater system.

Spatial and temporal water balance estimates quantify the components of the conceptual model. They provide groundwater managers with 
information on the quantitative effect of climate and the interactions between surface and groundwater. The GIS-based method can be a useful step between the conceptual and numerical groundwater model.

The data requirements of both GIS-based and full numerical models are similar, but the former relies almost entirely on measured data. The GIS-based method is more time-efficient but only generates water balances. Water surfaces, such as MODFLOW generates, could provide an additional means of checking model input.

The case study sensitivity analyses suggest that this water balance is relatively insensitive to all estimated parameters except those associated with evapotranspiration. However, the iterative cycle of back calculating recharge from the other parameters, converting it to a proportion of rainfall, deciding if this is feasible, then readjusting the evapotranspiration parameters provided bounds for the evapotranspiration.

The study shows the effect on the hydrologic components of the 1991 flood and the more subtle effects of the reduced level of pumping from 1993. It estimates the contributions of the individual hydrologic components to the water balance, both spatially and temporally.

A narrow, 4 kilometre long, north-south oriented area with a flat groundwater gradient, shown by the 5 metre contour in Figure 2, was unexpected. The groundwater flow directions inferred from the hydraulic head surface imply that groundwater from more than half of the study area passes through the northern end of this feature. More groundwater monitoring bores could verify this unusual feature.

Since the original work was completed QDNR\&M have drilled more bore holes and are updating the water balance model. They hope to then have a MODFLOW model developed independent of the water balance model. They plan to use the water balance model in the evaluation of the MODFLOW model. They will be modifying their groundwater management policies and are hoping to increase compliance by irrigators with water allocation limits. [pers. comm. Gary Jensen, QDNR\&M, November 2005].

\section{ACKNOWLEDGEMENTS}

The author is grateful to Teemu Kokkonen, Tony Jakeman, Karina Budd and two anonymous reviewers for their detailed comments on the manuscript. Some figures are taken from Welsh [2002] and Welsh [2005] and the text closely follows the latter publication in some places. The author wishes to thank the Queensland Department of Natural Resources and Mines for providing the hydrologic data used in this work.

\section{REFERENCES}

Australian Water Association, Australian Non Major Urban Water Utilities performance monitoring report 2000-2001. Australian Water Association Limited, Artarmon, New South Wales, 2002.

Baskaran, S., Brodie, R.S., Budd, K.L. and A.J. Plazinska, Assessment of Groundwater quality and origin of saline groundwaters in the coastal aquifers of Bowen area, North Queensland. Bureau of Rural Sciences, Canberra, 2001.

Freeze, R.A. and J.A. Cherry, Groundwater. Prentice-Hall Inc., Englewood Cliffs, N.J., U.S.A, 1979.

Jakeman, A.J., Letcher, R.A. and J.P. Norton, Ten iterative steps in development and evaluation of environmental models. Environmental Modelling \& Software, 21, 602-614, 2006.

McDonald, M.G. and A.W. Harbaugh, A modular three-dimensional finite-difference groundwater flow model. Techniques of WaterResources Investigations of the United States Geological Survey. Book 6, Chapter A1. US Department of the Interior, USA, 1988.

Middlemis, H. Groundwater flow modelling guideline. Murray-Darling Basin Commission, Canberra, 2000. http://www.landmark.mdbc.gov.au/publicatio ns/pdf/model_guide.pdf

Queensland Department of Natural Resources and Mines, Water Management in the Lower Burdekin, Phase 2 (incorporating Phase 1): Groundwater Model Conceptualisation. Department of Natural Resources and Mines, Queensland, 2000.

Queensland Department of Natural Resources and Mines, Water Management in the Lower Burdekin, Phase 3: Numerical Model Development. Department of Natural Resources and Mines, Queensland, 2001.

Water Resources Commission, Review of water resources Bowen area. Queensland Water Resources Commission, 1988.

Welsh, W.D. Conceptual hydrogeological model and water balance estimates for the Bowen irrigation area, Queensland. Bureau of Rural Sciences, Canberra, 2002.

Welsh W.D. Spatial and temporal water balance estimates using a GIS, in Proceedings of the 29th Hydrology and Water Resources Symposium - Water Capital, Canberra, 20- 
23 February 2005. Engineers Australia CD, 2005.

http://eprints.anu.edu.au/archive/00003037/ 